graded? Findings on 356,222 primary screenees of the multiple risk facto

Oliver MF. Serum cholesterol: the knave of the heart and the joker. Lance 1981;ii:1090-5

8 Goldbourt $\mathrm{C}$, Holtzman E, Neufeld HN. Total and high-density lipoprotein cholesterol in the serum and risk of mortality: evidence of a threshold effect. B.117 1985:290:1239-43

$9 \mathrm{Li}$ WX. Coronary heart disease survey in factories and countryside. Acta Academiae Medicinae Primae Shanghai 1979;6:65-75.

10 Zak B, Dickenman RC, White EG, Burnett H, Chernev PJ. Rapid estimation of free and total cholesterol. Am f Clin Pathol 1954;24:1307-15.

11 Pearson S, Stern A, McGavack TH. A rapid, accurate method for the determination of total cholesterol in serum. Anal Chem 1953;25:813-4

Keil $\mathrm{U}$, Kuulasmaa $\mathrm{K}$. The WHO MONICA project: risk factors Int f Epidemiol 1989; 18(suppl 1):S+6-55.

13 Han QQ, Yan XP, Zhuang HZ. Enzymic determination of serum cholesterol using homemade reagents. Acta Academiae Medicinae Primae Shanghat

It MacMahon S, Peto R, Cutler J, Collins R, Sorlie P, Neaton J, at al. Blood pressure, stroke and coronary heart disease. 1 . Prolonged differences in blood pressure: prospective observational studies corrected for the regression dilution bias. Lancet 1990;335:765-74.

15 Peto R, Pike MC, Armitage P, Breslow NE, Cox DR, Howard SV, et al. Design and analysis of randomised clinical trials requiring prolonged observation of each patient: II. Analysis and examples. $\mathrm{Br} / \mathrm{F}$ Cancer

16 Cox DR. Regression models and life tables (with discussion). Foumal of the Roval Statistical Society 1972;34:187-220.

17 Berkson J. Are there two regressions? Foumal of the American Statistical Associution 1950;45: 164-80.

18 Ederer F. Serum cholesterol changes: effects of diet and regression towards the mean. 7 ( Chronic Dis 1972;25:277-89.

19 Peto R. Two properties of multiple regression analysis; and regression to the mean and regression from the mean). In: Fletcher CM, Peto R, Tinker CM Speizer $\mathrm{FE}$, eds. The nutural history of chronic bronchitis and emphysema. An eight year study of early chromic obstructive lung disease in working men in London. Oxford: Oxford University Press, 1976:218-23.

20 Chen ZM. Collins R, Peto R, Li WX. No association between serum cholesterol and stroke rates in a Chinese population. $N$ Engl $\mathcal{f} \mathrm{Med}$ 1989:321:1339-40

21 Keys A. Seven countrics: a multizariate analysis of health and coronary hear disease. Harvard: Harvard University Press, 1980.

22 Simons LA. Interrelations of lipids and lipoproteins with coronary artery disease mortality in 19 countries. A $m$ f Cardiol 1986;57:5-10G.

23 Robertson TL, Kato H, Gordon T, Kagan A, Rhoads GG, Land CE, et al. Epidemiologic studies of coronary heart disease and stroke in Japanese men living in Japan, Hawaii and California. Incidence of myocardial infarction and death from coronary heart disease. Am 7 Cardiol 1977;39:239-43.

4 Szatrowski TP, Peterson AV, Shimizu Y, Prentice RL, Mason MW Fukunaga $\mathrm{Y}$, et al. Serum cholesterol levels, other risk factors, and cardiovascular disease in a Japanese cohort. $\mathcal{F}$ Chronic Dis 1984;7:569-84.

25 Iso H, Jacobs DR, Wentworth D, Neaton JD, Cohen J. Serum cholester levels and six-year mortality from stroke in 350,977 men screened for the MRFIT. N Engl f. Med 1989;320:904-10.
26 Li SC, Schoenberg BS, Wang CC, Cheng XM, Bolis CL, W'ang KJ, et al. Cerebrovascular disease in the People's Republic of China: epidemiologic and clinical features. Neurologv 1985;35:1708-12.

27 Chen DY, Wu GS, Wu CS, Hong SG, Zhang M, Zhao D. Incidence and diagnostic features of stroke in Beiiing population. Chin Med f 1987:7 382-6.

28 Rose (i, Shipley MJ. Plasma lipids and mortality: a source of error. Lancet $1980 ; \mathrm{i}: 523-6$

29 International Collaborative Group. Circulating cholesterol level and risk of death from cancer in men aged 40 to 69 years. Experience of an international collaborative group. FAMA 1982;248:2853-9.

30 Sherwin RW, Wentworth DN, Cutler JA, Hulley SB, Kuller LH, Stamler J. Serum cholesterol levels and cancer mortality in 361662 men screened for

31 Feinleib M. On a possible inverse relationship between serum cholesterol and cancer mortality. Am $\mathcal{f}$ E pidemiol 1981;114:5-10.

32 Williams RR, Sorlie PD, Feinleib M. Cancer incidence by levels of cholesterol. ЭAMA 1981;245:247-52.

33 Beaglehole R, Foulkes MA, Prior IA, Eyles EF. Cholesterol and mortality in New Zealand Maoris. $B M \mathcal{F}$ 1980;280:285-7.

34 Schatzkin A, Hoover RN, Taylor RR, Ziegler R, Carter CL, Larson DB, et al. Serum cholesterol and cancer in the NHANES I epidemiologic follow-up study. Lancet 1987;ii:298-30

35 Isles CG, Hole DJ, Gillis CR, Hawthorne VM, Lever AF. Plasma cholesterol coronary heart disease, and cancer in the Renfrew and Paisley survey. BM 1989;298:920-4.

36 Salonen JT. Risk of cancer and death in relation to serum cholesterol: a longitudinal study in an eastern Finnish population with high overall cholesterol level. Am f Epidemiol 1982;116:622-30.

37 Dyer AR, Stamler J, Paul O. Serum cholesterol and risk of death from cancer and other causes in three Chicago epidemiological studies. $\mathcal{J}$ Chronic $D$ is 1981;34:249-60.

38 Tornberg SA, Holm LE, Carstensen JM, Eklund GA. Risks of cancer of the colon and rectum in relation to serum cholesterol and beta-lipoprotein. $\checkmark$ Engl f Med 1986;315:1629-33.

39 Jiang YT. Epidemiological studies of viral hepatitis A and B in the People's Republic of China. In: Szmuness W, Alter HJ, Maynard JE, eds. Viral hepatitis. Philadelphia, PA: Franklin Institute Press, 1982:121-8

40 Beasley RP, Lin CC, Hwang LY, Chien CS. Hepatocellular carcinoma and hepatitis B virus. A prospective study of 22707 men in Taiwan. Lancet hepatitis B virus.

41 Muldoon MF, Manuck SB, Matthews KA. Lowering cholesterol concentra tions and mortality: a quantitative review of primary prevention trials. $B M$

42 Peto R, Yusuf S, Collins R. Cholesterol-lowering trial results in their epidemiologic context [abstract]. Circulation 1985;72:451.

+3 Pekkanen J, Nissinen A, Punsar S, Karvonen MJ. Serum cholesterol and ris of accidental or violent death in a 25 -year follow-up. The Finnish cohorts of the seven countries study. Arch Intern Med 1989; 149: 1589-91.

H Chen IS, Campbell TC, Li JY, Peto R. Diet, hifestyle and moriality in China: study of the characteristics of 65 Chinese counties. Oxford: Oxford University Press, 1990.
Department of Psychiatry, Royal Free Hospital,

London NW3 2 QG

David V James, MRCPSYCH, senior registrar

Broadmoor Hospital, Crowthorne, Berkshire

Lyle W Hamilton, MRCPSYCH, consultant

Correspondence to: Dr James.

BMF 1991;303:282-5

\title{
The Clerkenwell scheme: assessing efficacy and cost of a psychiatric liaison service to a magistrates' court
}

\author{
David V James, Lyle W Hamilton
}

\section{Abstract}

Objective-To determine the efficacy of psychiatric liaison schemes to magistrates' courts in shortening the period that mentally ill accused people spend in custody between arrest, the provision of psychiatric reports, and admission to hospital under the Mental Health Act 1983 and to establish the direct costs of setting up such schemes.

Design-A nine month prospective study of court referrals and concurrent analysis of prison records.

Setting-An inner London magistrates' court (Clerkenwell) and a large remand prison (Brixton).

Patients-Consecutive series of $\mathbf{8 0}$ remand prisoners receiving psychiatric assessment through a liaison scheme; 50 remand prisoners placed on hospital orders by magistrates' courts after being remanded to prison for reports; 364 psychiatric prisoners undergoing second opinion assessments at a remand prison; 520 offenders in a remand prison placed on hospital orders.

Main outcome measures-Comparison of lengths of time spent in custody for different stages of the assessment and disposal process.

Results-For the $\mathbf{5 0}$ remand prisoners assessed in prison the mean time from arrest to appearance in court with a psychiatric report was 33.7 days and from arrest to admission to hospital $\mathbf{5 0 . 8}$ days. For those examined in court under the liaison scheme the equivalent figures were 5.4 days $(t=12.63, \mathrm{p}<0.0001)$ and 8.7 days $(t=13.04, p<0.0001)$. The number of hospital orders made at the court increased fourfold after the liaison scheme began. The additional direct costs of the scheme were negligible.

Conclusion-Psychiatric liaison services to magistrates' courts can greatly reduce the length of time that offenders with mental disorders spend in custody. Such schemes may increase recognition of offenders suitable for admission to hospital. A scheme could be established in some areas within existing service provision.

\section{Introduction}

People who are accused of criminal offences and thought to be mentally disordered may spend consider able periods in custody on remand so that psychiatric reports can be prepared by catchment area services. Yet conditions in remand prisons are in general not suitable for the care of mentally disordered people. ${ }^{12}$ Treatment in such settings is problematical in that the 
treatment provisions of the Mental Health Act do not apply, and prisoners cannot be medicated against their will, except under common law. Concern has arisen about the number of suicides, and the regimens and conditions of detention have been harshly criticised..$^{1-4}$

Those remanded for reports will include seriously mentally disordered people who are in need of hospital treatment, some who do not have any form of treatable mental disorder, and a proportion who need only outpatient treatment. ${ }^{56}$ Some of those detained would normally have been bailed for reports were it not for residential instability. Some will be accused of nonimprisonable offences, and others will be detained on remand for longer than the period for which they were liable to be sentenced.

The traditional system for acquiring psychiatric reports is cumbersome and unsatisfactory. Once a mental disorder is suspected by the prison or the court a request is made by the prison medical service for a second opinion from the catchment area psychiatric service. A period elapses before the psychiatrist is able to attend the prison to make an assessment. There is then a further delay until the case next comes to court. If the court makes a hospital order under the Mental Health Act a further period in custody follows until the receiving hospital offers a bed.

A recent Home Office circular has encouraged the adoption of new strategies and initiatives to improve the treatment of mentally disordered offenders and to divert such people away from custody. ${ }^{8}$ One such strategy concerns the establishment of psychiatric services to magistrates' courts, which in London deal with $96 \%$ of criminal cases. The aim of such schemes is to intervene at an early stage in the remand process to remove mentally disordered offenders from the criminal justice system and put them into psychiatric care. As yet there has been little published experience of such schemes in the United Kingdom. ${ }^{9}$ We did this study to provide a quantitative evaluation of the efficacy and cost effectiveness of a liaison scheme by comparing those remand prisoners passing through the scheme with a series of remand prisoners obtaining psychiatric assessment in prison in the traditional manner.

\section{Patients and methods}

\section{PSYCHIATRIC LIAISON SCHEME}

The service was established between the department of psychiatry at the Royal Free Hospital and Clerkenwell and Hampstead Magistrates' Courts, sitting at Clerkenwell. The structure of the service was as follows. Two psychiatrists attended court one day a week to examine people in custody for whom psychiatric reports had been requested. Those appearing in court on days when the psychiatrists were not present were remanded until the day of the psychiatrists' next visit. Information about each case was available at court from the Crown Prosecution Service files, defence solicitors, and probation officers. Further background information was gathered from

TABLE I - Mean (95\% confidence interval) number of days spent in custody by 50 offenders on hospital orders after second opinion reports at Brixton Prison and 80 offenders referred to liaison scheme

\begin{tabular}{|c|c|c|c|c|}
\hline Stage of process & $\begin{array}{l}\text { Assessment at } \\
\text { remand prison } \\
(\mathrm{n}=50)\end{array}$ & $\begin{array}{c}\text { Assessment under } \\
\text { liaison scheme } \\
(\mathbf{n}=80)\end{array}$ & $\mathrm{p}$ Value & $t$ \\
\hline $\begin{array}{l}\text { Arrest to request for } \\
\text { assessment }\end{array}$ & $5 \cdot 8(3-7$ to $7 \cdot 8)$ & $5 \cdot 4(4 \cdot 0$ to $6 \cdot 7)(n=74)^{\star}$ & & \\
\hline Request to assessment & $15 \cdot 1(11 \cdot 2$ to $18 \cdot 9)$ & $0(n=74)^{\star}$ & & \\
\hline Arrest to assessment & $20 \cdot 8$ (16.6 to $24 \cdot 9)$ & $5 \cdot 4(4 \cdot 0$ to $6 \cdot 7)(n=74)^{\star}$ & $<0 \cdot 0001$ & $8 \cdot 25, \mathrm{df}=122$ \\
\hline Assessment to hospital order & $12 \cdot 9(9 \cdot 9$ to $15 \cdot 9)$ & $1.8(0.7$ to 2.9$)(\mathrm{n}=39)$ & $<0.0001$ & $6 \cdot 48, \mathrm{df}=87$ \\
\hline Arrest to hospital order & $33 \cdot 7(28 \cdot 6$ to $38 \cdot 8)$ & $8.5(5.8$ to $11 \cdot 1)(\mathrm{n}=35)^{\star}$ & $<0.0001$ & $7 \cdot 71, \mathrm{df}=83$ \\
\hline Hospital order to admission & $16 \cdot 9(14 \cdot 6$ to $19 \cdot 2)$ & $0.3(0$ to 0.5$)(\mathrm{n}=37) \dagger$ & $<0.0001$ & $12 \cdot 47, \mathrm{df}=85$ \\
\hline Arrest to admission & $50 \cdot 8(45 \cdot 9$ to $55 \cdot 6)$ & $8.7(5.9$ to 11.4$)(\mathrm{n}=33)^{\star} \dagger$ & $<0.0001$ & $13 \cdot 04, \mathrm{df}=81$ \\
\hline
\end{tabular}

hospitals, general practitioners, and social service departments by fax and telephone. The psychiatrists examined those referred in the cell area and gave oral reports to the court on the same day. Recommendations were completed for hospital admission under both part 2 (the civil sections) and part 3 (the court sections) of the Mental Health Act 1983. Where hospital orders were made direct admission to hospital from the court was arranged if possible.

\section{METHODS}

As a preliminary investigation court records were used to ascertain the number of people placed on hospital orders at the courts in question during the 18 months before the liaison scheme to the court began. The length of time that those put on orders had spent in custody from arrest until the making of the order was ascertained, as well as the number of days between the hospital order being made and admission to hospital. In this retrospective sample numbers were likely to be small and only two courts were involved. Therefore a larger, more representative sample was investigated. Data were collected on 50 consecutive cases placed on hospital orders by London magistrates' courts after being remanded to Her Majesty's Prison, Brixton, a large remand prison, for the preparation of reports. This sample was contemporaneous with our liaison scheme at Clerkenwell. The number of days spent in custody for each period of the assessment process from arrest to arrival in hospital was recorded. Background data on the people concerned were gathered.

Two of the periods in the assessment process were of particular interest in that they could directly be influenced by psychiatric services. These were the length of time from the request for a second opinion from the catchment area service until the assessmen was made and the number of days in custody between a hospital order being made and admission to hospital. It was decided to look at these in larger samples from the remand prison. The first was examined in a consecutive series of those receiving second opinion assessments at the remand prison. The second was examined in a consecutive series from the prison of people placed on hospital orders.

Data on remand length and background information were gathered for all those assessed by the liaison service to Clerkenwell Court over nine months. The length of time on remand for each stage of the process was compared for those processed by the liaison service and those processed through the remand prison. Several characteristics of the two groups were compared by Student's $t$ test and the $\chi^{2}$ test.

\section{Results}

During the 18 months before the liaison scheme began only 18 hospital orders were made by the two courts in question, an average of one per month. This represents $0 \cdot 24 \%$ of those appearing before the court on criminal charges. The mean time in custody from arrest to admission was 61.9 days, of which 13.8 davs were spent waiting for a hospital bed after the order had been made.

Table I gives the results for the main groups studied. For the 50 placed on hospital orders after second opinion reports at the prison the mean ( $95 \%$ confidence interval) time from arrest to admission was 50.8 (45.9 to $55 \cdot 6)$ days, of which $15 \cdot 1(11 \cdot 2$ to 18.9$)$ days were spent awaiting the requested assessment, $12.9(9.9$ to 15.9) days waiting for the case to be dealt with after the assessment, and $16.9(14.6$ to $19 \cdot 2)$ days waiting for a hospital admission after a hospital order had been made by the court. The length of time that it takes for a second opinion to be given in prison after a request to 
the catchment area service was further examined for 364 consecutive second opinions given at the remand prison. This included both cases in which a hospital order was advised and cases in which other disposals were recommended. The mean $(95 \%$ confidence interval) number of days spent awaiting assessment was $13.1(11.7$ to 14.4$)$. There was no significant difference between this larger group and the group of $50(t=1 \cdot 21, \mathrm{df}=412)$. The time taken for the hospital to admit the patient after the hospital order had been made was further examined in a consecutive sample of 520 remand prisoners. The average time was 14.98 $(13.7$ to $16 \cdot 2)$ days. There was no significant difference between this and the figure for the group of 50 $(t=1 \cdot 64, \mathrm{df}=568)$.

Over nine months there were 80 referrals to the liaison scheme established at Clerkenwell Court. In six cases the magistrate bailed the defendant overnight to see the psychiatrists at court, although this was not the intention of the scheme. The psychiatrists recommended admission in 39 cases (nearly a half of referrals) under both parts 2 and 3 of the Mental Health Act. The recommendations were accepted in all cases by the court, although two patients failed to arrive at their destination. Of the total of 39 hospital orders made, 25 (64\%) were under part 2 (the civil sections) of the act, section 2 assessment orders being used in $20(80 \%)$ of these cases and section 3 treatment orders in the remainder. Changes were discontinued in all but four of these cases. The remaining $14(36 \%)$ of the total were put on section 37 treatment orders under part 3 (court sections) of the act. Section 37 was used where the Crown Prosecution Service (or the psychiatrists) deemed it in the public interest that a conviction be recorded and on three occasions when no approved social worker could be found to make an application for a civil order. Civil orders were on occasion preferred where the receiving hospital agreed to take the patient under part 2, but not under part 3 without a review by their own nursing and medical teams.

In those reaching hospital through the liaison scheme, the mean ( $95 \%$ confidence interval) number of days from arrest to admission was $8.7(5.9$ to 11.4$)$ compared with $50.8(45.9$ to 55.6$)$ for the sample processed through the traditional system $(t=13.04$, $\mathrm{df}=81 ; \mathrm{p}<0.0001)$. This was accomplished because the scheme virtually abolished three of the waiting periods: those from the request for assessment to assessment, from assessment to the order being made, and from the order being made to admission to hospital. However, holding offenders on remand overnight sometimes proved necessary due to a shortage of approved social workers (nine cases), lack of transport (two cases), and lack of beds (three cases). Two patients placed on orders failed to arrive in hospital. One absconded and one hanged himself in Brixton Prison while awaiting a hospital bed.

For those assessed under the liaison scheme, but not sent to hospital, the mean time from arrest to appearance in court with a report was $5 \cdot 4(4.0$ to $6 \cdot 7)$ days. This compares with 33.7 (28.6 to 38.8$)$ days for those receiving second opinion assessments in prison $(t=12 \cdot 63, \mathrm{df}=122 ; \mathrm{p}<0 \cdot 0001)$.

Table II compares the characteristics of those processed through the traditional system and those assessed at Clerkenwell. No significant differences were found in the variables studied. Twenty three different catchment hospitals (and thus areas of domicile) received the patients from the Brixton sample and 15 those from Clerkenwell. The remand prison in this study contained only men, whereas those referred to the liaison service comprised $25 \%$ women, and of those sent to hospital through the scheme $21 \%$ were women. In all, $51(85 \%)$ of the men referred in the liaison scheme were held in the remand prison under study
TABLE II-Characteristics of offenders admitted to hospital who were processed through Brixton Prison or the liaison scheme

\begin{tabular}{|c|c|c|c|}
\hline & $\begin{array}{c}\text { No }(\%) \\
\text { assessed at } \\
\text { Brixton } \\
\text { Prison } \\
(\mathrm{n}=50)\end{array}$ & $\begin{array}{c}\text { No (\%) } \\
\text { assessed at } \\
\text { Clerkenwell } \\
(\mathbf{n}=33)^{\star}\end{array}$ & Significance \\
\hline \multicolumn{4}{|l|}{ Age: } \\
\hline$<20$ & $0(0)$ & $1(3)$ & \multirow{6}{*}{$\begin{array}{l}t=1 \cdot 1027, \mathrm{df}=8 \\
\mathrm{p}=0 \cdot 3\end{array}$} \\
\hline $20-29$ & $23(46)$ & $15(45)$ & \\
\hline $30-39$ & $14(28)$ & $6(18)$ & \\
\hline $40-49$ & $9(18)$ & $6(18)$ & \\
\hline $50-59$ & $4(8)$ & $2(7)$ & \\
\hline$\geqslant 60$ & $0(0)$ & $3(9)$ & \\
\hline \multicolumn{4}{|l|}{ Homeless at arrest: } \\
\hline Yes & $12(24)$ & $8(24)$ & \multirow{2}{*}{$\begin{array}{l}0.000, d f=1 \\
p=0.97\end{array}$} \\
\hline No & $38(76)$ & $25(76)$ & \\
\hline \multicolumn{4}{|l|}{ Known criminal record: } \\
\hline Yes & $42(84)$ & $27(82)$ & \multirow{2}{*}{$\begin{array}{l}0 \cdot 000, d f=1 \\
p=0 \cdot 97\end{array}$} \\
\hline No & $8(16)$ & $6(18)$ & \\
\hline \multicolumn{4}{|c|}{ Known past psychiatric admission: } \\
\hline Yes & $36(72)$ & $24(73)$ & \multirow{2}{*}{$\begin{array}{l}0.03, d f=1 \\
p=0.86\end{array}$} \\
\hline No & $14(28)$ & $9(27)$ & \\
\hline \multicolumn{4}{|l|}{ Offence: } \\
\hline Thefts & $12(24)$ & $9(28)$ & \multirow{5}{*}{$\begin{array}{l}0.29, \mathrm{df}=4 \\
\mathrm{p}=0.99\end{array}$} \\
\hline Assaults & $12(24)$ & $8(24)$ & \\
\hline Criminal damage & $12(24)$ & $8(24)$ & \\
\hline Indecency & $6(12)$ & $4(12)$ & \\
\hline Public order offences & $8(16)$ & $4(12)$ & \\
\hline \multicolumn{4}{|l|}{ Diagnosis: } \\
\hline Schizophrenia and allied states & $41(82)$ & $29(88)$ & \multirow{3}{*}{$\begin{array}{l}0.17, d f=1 \\
p=0.67\end{array}$} \\
\hline Mania & $7(14)$ & $4(12)$ & \\
\hline Other & $2(4)$ & $0(0)$ & \\
\hline
\end{tabular}

*Number arriving in hospital (33) was two less than the number of orders made as one patient absconded and one hanged himself in custody. Orders made on those on bail are excluded.

†By $\chi^{2}$ test unless otherwise stated.

but were excluded from the prison study groups. There were no significant differences between men and women handled by the liaison scheme either in time from arrest to appearance in court with a report $(t=1.05, \mathrm{df}=72)$ or in time from arrest to admission $(t=1 \cdot 48, \mathrm{df}=31)$. When the men handled by the liaison scheme are compared with those processed through the prison the differences in length in custody remain highly significant (arrest to court appearance with report $t=10 \cdot 68, \mathrm{df}=104, \mathrm{p}<0.0001$; arrest to admission $t=11 \cdot 43, \mathrm{df}=74, \mathrm{p}<0.0001$ ).

In all, $1.9 \%$ of offenders appearing before Clerkenwell court were referred to the liaison scheme, and $0.96 \%$ were admitted to hospital. This represents a hospital order rate of 4.3 a month, which is four times higher than that for the 12 months before the scheme began, after adjusting for a $9 \%$ increase in those appearing before the court between the two periods. Hospital orders on people charged with assaults increased by a factor of $2 \cdot 7$, but orders in crimes not involving personal violence increased fivefold. No significant differences were found (by Fisher's exact test) between those seen at Clerkenwell before and during the scheme in age, sex, offences of violence, homelessness, diagnosis, previous psychiatric admission, or previous conviction.

\section{Discussion}

The psychiatric liaison scheme to the magistrates' court resulted in a considerable decrease in the number of days that those remanded for psychiatric reports spent in custody when compared with the traditional practice of obtaining second opinions at the remand prison. This reduction was greater than $80 \%$, both for those sent to hospital and those not.

For those placed on hospital orders the scheme achieved this reduction both by accelerating the provision of a report to the court and by arranging admission to hospital on the day the order was made. Notably, those placed on orders through the traditional system had to spend on average a further two weeks in custody before a hospital bed was 
provided. All hospitals provide beds for those placed on part 2 (civil) orders on the day the order is made. It is illogical that, unless approached by a scheme such as ours, they do not routinely do the same for those placed on part 3 (court) orders.

The fourfold increase in the number of hospital orders made by the courts in this study after the scheme began is difficult to attribute to factors other than the presence of the psychiatric liaison service and its influence on referral patterns. The change was immediate and sustained, and there was no increase in the use of hospital orders by inner London magistrates' courts as a whole over the period in question..$^{10} \mathrm{An}$ increase occurred in all types of offences, suggesting a higher detection rate of cases suitable for hospital disposal. The greater increase in orders for those charged with offences not involving violence supports the hypothesis that readier access to psychiatrists at Clerkenwell encouraged the referral of some mentally disordered people who might previously have not been referred as their outward behaviour was not severely disturbed.

The scheme received no funding and functioned within existing service provision. A modest grant for secretarial and administrative support would have been useful. The only cost of the scheme to the court was the standard expert witness fee that the psychiatrists could (if they choose to) claim for each patient on whom they gave evidence. Assessment at remand prisons commands a similar fee.

The cost of keeping a person in Brixton Prison at the beginning of the liaison scheme was $£ 442$ a week." Given the substantial reduction in remand lengths achieved by the liaison scheme substantial savings in remand costs are possible, but it would be necessary to enable the closure of an entire remand wing before a direct equation could be made. The inter-relation of costs between prison and health care is difficult to calculate. For those not admitted to hospital after assessment - usually the majority ${ }^{4}$ - the probability of overall savings is greater, at least for those not receiving custodial sentences. But for all those swiftly removed into hospital under the liaison scheme costs are in effect transferred from prison to hospital budgets. ${ }^{12}$ It is arguable that early hospital admission may reduce the length of costly hospital stay and also improve long term prognosis.

Further research is needed to establish whether liaison schemes have any effect on long term outcome, both in terms of readmission and reoffending. The Home Office circular on provision for mentally disordered offenders states in the section on magistrates' courts that "a mentally disordered person should never be remanded to prison simply to receive medical treatment or assessment." The establishment of more psychiatric liaison schemes to magistrates' courts, particularly in inner city areas, presents an effective way of bringing this ideal closer.

We thank Mr Michael Pascoe, senior chief clerk; Ms Amanda Brown, senior probation officer; and $\mathrm{Mr}$ Paul Thompson, senior social worker, for making the scheme possible. We are grateful to Her Majesty's Prison Brixton and the Home Office for their cooperation and Mr Bob Blizzard for statistical support. We thank Professor John Gunn and an anonymous reviewer for their helpful comments on an earlier draft of this paper. The views expressed in this article are those of the authors, and do not necessarily represent those of any official body. 1 Home Office. Report of Her Majesty's Chief Inspector of Prisons 1989.
London: HMSO, 1990. (House of Commons paper 589.)

2 Home Office. HMP Brixton: Report by HM Chief Inspector of Prisons. London Home Office, 1990.

3 Her Majesty's Stationery Office. Prison disturbances: April 1990. London HMSO, 1991. (The Woolf/Tumin report, Cmnd 1456.)

4 Herbst K, Gunn JC, eds. The mentally disordered offender. London: Butterworth-Heinemann, 1991

5 Bowden P. Men remanded into custody for medical reports; the outcome of the treatment recommendations. Brf Psychiatry 1978;132:332-8.

6 Faulk M, Trafford PA. Efficacy of medical remands. Med Sci Law 1975;15: 276-9.

7 Gibbens TCN, Soothill KL, Pope PJ. Medical remands in the criminal court. Oxford: Oxford University Press, 1977.

8 Home Office. Provision for mentally disordered offenders. London: Home Office, 1990. (Circular 66/90.)

9 Joseph PL, Potter M. Mentally disordered homeless offenders: diversion from custody. Health Trends 1990;22:51-3.

10 Inner London Magistrates' Courts' Committee. Report of the Inner London Magistrates' Courts Service for the year 1990 (in press).

11 Her Majesty's Stationery Office. Annual report of the work of the prison service, April 1989 to March 1990. London: HMSO, 1990. (Cmnd 1302.)

12 Fennell P. Diversion of mentally disordered offenders from custody. Criminal Law Review 1991:333-48.

(Accepted 4 fuly 1991)

\section{Outcome of brittle diabetes}

\author{
G V Gill, K G M M Alberti
}

The Diabetes Centre, Walton Hospital, Liverpool L9 1AE

G V Gill, FRCP, consultant physician

University Department of Medicine, The Medical

School, Newcastle upon Tyne NE2 4HH

K G M M Alberti, FRCP,

professor of medicine

Correspondence to: Dr Gill.

BMF 1991;303:285-6

A brittle diabetic patient is one whose life is constantly disrupted by episodes of hyperglycaemia or hypoglycaemia of any cause. ${ }^{1}$ The condition occurs in a minority of insulin dependent patients and usually results in repeated admission to hospital. An important type of brittle diabetes is characterised by recurrent attacks of ketoacidosis in young female patients. The clinical characteristics in these patients are remarkably stereotyped and they thus provide a useful model to study the long term outcome of brittle diabetes. We have followed up 20 such diabetic patients for a mean of eight years.

\section{Patients, methods, and results}

Between August 1979 and September 1985, 20 young females with $\mathrm{C}$ peptide negative, insulin dependent diabetes were referred to the Freeman Hospital, Newcastle upon Tyne, because of severely life disrupting recurrent ketoacidosis. Their mean age was $18 \cdot 8(\mathrm{SD} 4 \cdot 1)$ years and mean duration of diabetes was $7 \cdot 7(4 \cdot 2)$ years. We sought follow up information on these women between March and November 1989, a mean of $8 \cdot 2(1.4)$ years (range $5 \cdot 0-10 \cdot 0$ years) after initial assessment. Each patient's consultant was contacted and asked for current clinical details (type and dose of insulin received, body weight, recent glycated haemoglobin concentration, frequency of hospital admission in the past 12 months, and diabetic complications). The consultants were asked to state whether the patient was still considered brittle, using the definition above. We analysed the results using Student's $t$ test and the $\chi^{2}$ test with Yates's correction.

Two patients died during follow up: one of ketoacidosis and one during an operation to implant a peritoneal insulin infusion cannula. The table summarises the results for the remaining patients. Though glycaemic control remained poor at follow up, the doses of insulin and rates of admission to hospital were considerably reduced. Consultants thought that $10(56 \%)$ patients were no longer brittle and that four $(22 \%)$ had improved. The brittleness in two patients was unchanged and in two others it had become more problematic: both had required implantation of insulin pumps and one had had a 